\title{
The Evaluation of Fasting Plasma Glucose (FPG) Levels in Hypertensive Patients Using Calcium Channel Blocker (CCB) Drugs Class in Undata Regional Hospital
}

\author{
(Evaluasi Kadar Glukosa Plasma Puasa (GPP) pada Pasien Hipertensi Menggunakan \\ Obat Kelas Pemblok Kanal Kalsium di Rumah Sakit Daerah Undata)
}

\begin{abstract}
Amelia Rumi*, Anggun Fitriana
Department of Pharmacy, Faculty of Mathematics and Natural Sciences, Tadulako University, Palu, Indonesia *E-mail: amelia.rumi@gmail.com

Article Info:

Received: 2 March 2021

in revised form: 16 May 2021

Accepted: 8 October 202

Available Online: 10 October 2021

Keywords:

Hypertension

Calcium Channel Blocker

Fasting plasma glucose

Hyperglycemic

Corresponding Author:

Amelia Rumi

Department of Pharmacy

Faculty of Mathematics and Natural

Sciences

Tadulako University

Palu

90245

Indonesia

email: amelia.rumi@gmail.com

ABSTRACT

Background: Hypertension plays a major role in the development of heart disease which is one of the most leading causes of death worldwide. Antihypertensives must be selected carefully to avoid affecting metabolic parameters. A risky case involving the increase of plasma glucose levels using Calcium Channel Blocker (CCB) antihypertensive, amlodipine, has been reported. Objectives: This study aims to examine the effects of CCB treatments on blood glucose levels in hypertensive patients at the Undata Regional Hospital of Central Sulawesi Province. Material and Methods: This study used a cross-sectional design with a prospective approach. The instruments \& materials used in this study are Accu-Chek Performa glucometer along with the patient's blood sample material. The research subjects were 31 patients who met the inclusion criteria; patients had been treated with CCB therapy for 3 months, patients were not diagnosed with diabetes mellitus, and patients did not use drugs that might affect the blood glucose levels. Results: The results showed an average value of fasting plasma glucose (FPG) levels of hypertension patients using CCB class showed an increase from baseline of $124,619 \mathrm{mg} / \mathrm{dL}$ to $141,612 \mathrm{mg} / \mathrm{dL}$ with a difference of $16,993 \mathrm{mg} / \mathrm{dL}$. Statistical analysis also obtained a significance value of $\mathrm{p} 0,000$ which indicates that the use of amlodipine can significantly increase fasting patients' plasma glucose levels. Conclusions: If observed clinically, the increasing in fasting plasma glucose values falls into the category of mild to moderate hyperglycemic.
\end{abstract}

Copyright $(2019$ JFG-UNTAD This open access article is distributed under a Creative Commons Attribution (CC-BY-NC-SA) 4.0 International license.

How to cite (APA $6^{\text {th }}$ Style):

Rumi, A., Fitriana, A. (2021). The Evaluation of Fasting Plasma Glucose (FPG) in Hypertensive Patients Using Calcium Channel Blocker (CCB) Drug Class in Undata Regional Hospital. Jurnal Farmasi Galenika: Galenika Journal of Pharmacy (e-Journal), 7(2), 166-180. doi:10.22487/j24428744.2021.v7.i2.15463 


\begin{abstract}
ABSTRAK
Latar Belakang: Hipertensi berperan besar dalam perkembangan penyakit jantung yang merupakan penyebab utama kematian di seluruh dunia. Antihipertensi harus dipilih sedemikian rupa agar tidak mempengaruhi parameter metabolik. Sebuah risiko peningkatan kadar gula darah menggunakan antihipertensi golongan Calcium Channel Blocker (CCB) yakni amlodipin telah dilaporkan. Tujuan: Penelitian ini bertujuan untuk melihat pengaruh pemberian CCB terhadap kadar glukosa darah pasien hipertensi di Rumah Sakit Umum Daerah Undata Provinsi Sulawesi Tengah. Bahan dan metode: Adapun alat \& bahan yang digunakan dalam penelitian ini yakni menggunakan alat glucometer Accu-Chek Performa, dengan bahan sampel darah pasien. Penelitian ini menggunakan studi cross-sectional dengan pendekatan prospektif dengan jumlah sampel penelitian sebanyak 31 pasien yang memenuhi kriteria inklusi yakni pasien yang menggunakan terapi CCB selama 3 bulan, dan tidak terdiagnosis diabetes mellitus, dan tidak menggunakan obat yang mempengaruhi kadar glukosa darah. Hasil: Hasil penelitian menunjukkan nilai rata-rata kadar gula darah puasa pasien hipertensi yang menggunakan obat golongan CCB terdapat peningkatan rata-rata dari baseline 124,619 mg/dL menjadi 141,612 mg/dL dengan nilai selisih $16,993 \mathrm{mg} / \mathrm{dL}$. Analisis statistik diperoleh nilai signifikansi $p$ 0,000 yang menunjukkan bahwa penggunan obat golongan CCB yakni amlodipin signifikan dapat meningkatkan kadar gula darah puasa. Kesimpulan: Jika dilihat secara klinis, peningkatan nilai gula darah puasa ini masuk dalam kategori hiperglikemik ringan sampai sedang.
\end{abstract}

Kata kunci: Hipertensi, Calcium Channel Blocker, gula darah puasa, hiperglikemik

\title{
INTRODUCTION
}

Hypertension is one of the main causes of mortality and morbidity in Indonesia. According to the Ministry of Health of the Republic of Indonesia (2014), hypertension is an increase in systolic blood pressure of more than $140 \mathrm{mmHg}$ and an increase of diastolic blood pressure of more than $90 \mathrm{mmHg}$ on two measurements with an interval of five minutes in a state of sufficient rest/calm.

Cardiovascular disease globally causes around 17 million deaths each year, and from almost one-third of the total, hypertension complications contribute 9.4 million deaths worldwide yearly. The highest prevalence of hypertension occurs in Africa at around $46 \%$ while the lowest prevalence of $35 \%$ is found in America (World Health Organization, 2013). While in Indonesia itself, according to the Ministry of Health of the Republic of Indonesia (2018), the prevalence of hypertension based on measurements in 2013 was $25.8 \%$ and in 2018 it increased to $34.1 \%$. The prevalence of hypertension is based on a doctor's diagnosis or taking antihypertensive drugs in the population aged over than 18 years in 2018 based on the residence of the province. The highest is in North Sulawesi Province at $13.5 \%$, followed by East Kalimantan and Gorontalo Provinces. Sulawesi provinces were on the eighth-most prevalence of hypertension $(9 \%)$.

The development of hypertension cases, according to Health Office of Central Sulawesi Province (2017), showed an increase in hypertension cases every year, where in 2015 amounted as $3.61 \%$ increased to $5.03 \%$ in 2016, and increased even larger to $27.8 \%$ in 2017 . The highest percentage of hypertension in 2017 occurred in the Banggai Island Regency which reached 79.9\%, followed by the Toli-toli District of $73.9 \%$, while Palu City had the total of $44.5 \%$. 
A study conducted by researchers at Undata Regional General Hospital, Palu, it is discovered that Calcium channel blocker (CCB) is the antihypertensive agent that is often prescribed to hypertensive patients at Undata Regional General Hospital in Palu. CCB is the first-line therapy and an effective antihypertensive agent. CCB inhibited the entry of calcium across the cell membranes (DiPiro et al., 2017). Antihypertensive effects of CCB occurred through the inhibition of calcium channels in smooth muscle. The role of calcium which is causing contractility and maintaining the work of vascular muscles, when clashed with the inhibition of calcium, then the muscles of the blood vessels will relax, causing a decrease in blood vessel resistance and thus resulting in a decrease of blood pressure. The ability to block the calcium has the potential to cause hyperglycemia. CCB affects calcium L-type channels in the pancreas (Degeeter \& Taylor, 2018). According to Sushma et al., (2012) from the study conducted on albino rabbits without diabetes, the results obtained were significantly higher in the test group, where rabbits that had been given amlodipine orally than the test group that only used distilled water for 3 days of treatment. Pharmacologically, calcium has an important role in hormone metabolism and especially in carbohydrate homeostasis and glucoseinduced insulin secretion in the pancreas. The presence of calcium channel blocking agents can interfere with metabolic control and tend to interfere with insulin release, potentially causing hyperglycemia. Based on this previous literature, it is interested to study the effect of giving CCB on plasma glucose levels of hypertensive patients at Undata District General Hospital, Palu.

\section{MATERIAL AND METHODS}

\section{Materials}

This research was conducted by measuring fasting plasma glucose patients' levels two times, i.e. before and after 3 months. CCB therapy was given to the patients who received CCB group therapy in Undata Hospital Palu who met the inclusion criteria, namely: patients aged over than 18 years, patients who were willing to participate in the study, patients who had a history of hypertension and received CCB group antihypertensive therapy in the last 3 months, patients who are not diagnosed with diabetes mellitus and are not currently using other medications that affect plasma glucose levels.

\section{Methods}

The sampling technique used in this study is non-probability sampling, namely sampling that does not provide equal opportunities or opportunities for each element or member of the population to be selected as samples, using a purposive sampling approach where the sample is taken based on inclusion and exclusion criteria. The sample size used in this study was $\geq 30$ patients. Where a sample size of more than 30 and less than 500 is appropriate for most studies (Alwi, 2012). This study was 
approved by ethical committee of medical and health research, Faculty of Medicine, Tadulako University, with the number 6743/UN28.1.30/KL/2019.

As for the stages of this research, the researcher asked the willingness of the research subjects to give informed consent. If the research subjects were willing to participate in the research, researchers took fasting blood samples that were carried out in the morning after the study subjects had fasted for 8 hours, the researcher took fasting plasma glucose patients' samples bio-physiologically at their fingertips using the Accu-Chek Performa glucometer. The results of fasting plasma glucose patients' levels were used as the baseline after 3 months of CCB therapy, the measurement of fasting plasma glucose patients' level was repeated in the research subjects as an evaluation value, and then the data collected was analyzed descriptively and quantitatively. Descriptive analysis was carried out using data obtained from medical records including demographic characteristics, clinical characteristics, and profiles of drug use during the treatment process. Quantitative analysis was performed on the results of fasting plasma glucose patients' tests using the Shapiro Wilk normality test and Wilcoxon statistical test.

\section{RESULTS AND DISCUSSION}

The results of the study, as inferred from Table 1, showed that the total samples who received CCB therapy were 33 patients and those who met the criteria in the study were 31 patients.

Table 1. Number of patients who were treated with CCB group therapy at Undata Regional Hospital.

\begin{tabular}{lcc}
\hline No & Patients who receive CCB & Total \\
\hline 1 & Fulfilled all criteria & 31 \\
2 & Did not fulfill all criteria & 2 \\
& Total & 33 \\
\hline
\end{tabular}

Based on the sex of 31 hypertensive patients, there were 16 female patients $(51.61 \%)$ and 15 male patients $(48.38 \%)$. The female gender was more dominantly affected by hypertension. These results are in line with the statements said by Indonesia's Ministry of Health (2018), were from the results of Basic Health Research in 2018, the prevalence of hypertension was more common in female (36.9\%) compared to male $(31.3 \%)$. It is because female experienced estrogen hormone imbalance that occurs during pre-menopause and menopause. Hence, this was what caused an increase in blood pressure. According to Harigustian \& Dewi (2016), women are more at risk of developing hypertension. This is related to hormonal factors that are greater in a woman's body than a man. Hormonal factors can cause an increase in body fat or obesity. Obesity in women can also be caused by a lack of activity. More stress is also developed in women and more time spent relaxing at home. Table 2 displayed the age of patients suffering from hypertension were the most amount in the age range of 45-54 years with as many as 12 patients (41.93\%) due to the increasing age of blood vessel walls which undergone 
changes in structure and functions so that it caused the increase in blood pressure. Ages between 40-60 proved to have a risk in developing hypertension (Aryzki \& Akrom, 2018). The older of a person is, the greater the risk of developing hypertension. This is because, in old ages, structural and functional changes occur in the peripheral vascular system which is responsible for changes in blood pressure. Also, according to Saputra \& Indrawanto (2013), after the age of 45 years, the walls of the arteries will experience thickening due to the accumulation of collagen in the muscle layer, so the blood vessels will gradually narrow and become stiffer. Systolic and diastolic blood pressure increases because of the decreasing flexibility of large blood vessels which also increases with one's age. Based on the type of occupation shown in Table 2, it shows that patients with a job of Civilous Servants (PNS) had more hypertension consisting of as many as 13 patients (41.93\%). This is by research conducted by Harigustian \& Dewi (2016), where 10 patients out of 24 patients who were employed as civilous servants, a job which involves experiencing a high level of stress, have a risk of developing hypertension. Buziness, continuous working and lack of resting can increase the heart activity in pumping blood throughout the body to meet the body's needs in completing work activities.

Table 2. Demographic characteristics of hypertensive patients at Undata Hospital, Palu in the period of September-December 2019

\begin{tabular}{ccc}
\hline Patients' characteristic & $\begin{array}{c}\text { Number of patients } \\
(\mathbf{n = 3 1})\end{array}$ & Percentage (\%) \\
\hline Gender & 16 & \\
Female & 15 & $41,61 \%$ \\
Male & & \\
Ages & 13 & $41,93 \%$ \\
$45-54$ & 8 & $25,80 \%$ \\
$55-64$ & 9 & $29,03 \%$ \\
$65-74$ & 1 & $3,22 \%$ \\
$>75$ & & \\
Occupation & 9 & $29,03 \%$ \\
Midwife & 13 & $41,93 \%$ \\
Governments' officials & 5 & $16,12 \%$ \\
Entrepreneurs & 3 & $9,67 \%$ \\
Farmers & 1 & $3,22 \%$ \\
Construction workers & & \\
\hline
\end{tabular}

The clinical characteristics in Table 3 indicated that the symptoms most often experienced by patients in cardiac surgery at Undata Hospital Palu were chest pain, as mentioned by 21 patients (67.74\%). Chest pain is caused by an imbalance between the supply and oxygen demand of the heart. According to Starry (2012), chest pain is one of the most common complaints in the emergency room, and one of the main causes of chest pain is cardiovascular disorders. As stated by Barnett, Prior, Kadam, \& Jordan (2017), chest pain and shortness of breaths are common symptoms of cardiovascular disease, as observed in the primary care unit at Keele University, the incidence of chest pain ranges between 13 to 20 per 1000 people per year. Chest pain becomes one of the risk factors of cardiovascular morbidity 
and mortality. Also, as many as 17 patients (54.83\%) experienced palpitations and 15 patients (48.38\%) experienced back neck tension complaints. According to the World Health Organization (2013), hypertension may cause symptoms such as headaches, shortness of breath, dizziness, chest pain, palpitations.

Table 3. Clinical manifestations on hypertensive patients at Undata Regional Hospital.

\begin{tabular}{ccc}
\hline Clinical Manifestations & $\begin{array}{c}\text { Number of patients } \\
(\mathbf{n = 3 1})\end{array}$ & Percentage (\%) \\
\hline Palpitations & 17 & $54,83 \%$ \\
Chest pain & 21 & $67,74 \%$ \\
Fatigue & 3 & $10 \%$ \\
Dizzy & 3 & $10 \%$ \\
Shortness of breaths & 3 & $10 \%$ \\
Insomnia & 3 & $10 \%$ \\
Heartburn & 1 & $3,22 \%$ \\
The back of neck tense & 15 & $48,38 \%$ \\
Muscle cramps & 2 & $6,45 \%$ \\
\hline
\end{tabular}

In Table 4, the diagnosis elaborated that out of the 31 patients, there were 19 patients $(61.29 \%)$ with a diagnosis of Heart Disease (HHD). HHD is a term applied when referring to overall heart disease caused by an increase in blood pressure, both directly and indirectly (Anonymous, 2014). According to Lukito, Eka, \& Made (2019) and Waty \& Hasan (2013), hypertension plays a major role in the development of heart disease which is the leading cause of death worldwide. The development of hypertension generally begins with left ventricular hypertrophy, causing hypertension heart disease. The prevalence of hypertension continues to increase which resulted in the increasing of incidences of hypertension heart disease. According to DiPiro et al. (2017), uncontrolled hypertension can cause complications of other diseases. Hypertension has a strong correlation with the incidence of cardiovascular morbidities and mortalities. The occurrence of hypertension can cause a risk of stroke, myocardial infarction, angina, heart failure, and even early deaths caused directly by an increase in blood pressure. Blood pressure values ranging from 115/70 mmHg, may have a risk of cardiovascular disease that multiplies with every increase of $20 / 10 \mathrm{mmHg}$. Patients with blood pressure in the position of prehypertension also have a risk of developing cardiovascular disorders.

Table 4. Hypertensive patients' diagnosis at Undata Regional Hospital.

\begin{tabular}{ccc}
\hline $\begin{array}{c}\text { Complications and } \\
\text { Morbidities }\end{array}$ & $\begin{array}{c}\text { Number of patients } \\
(\mathbf{n = 3 1})\end{array}$ & Percentage (\%) \\
\hline$H H D$ & 19 & $61,29 \%$ \\
$C H F$ & 7 & $22,58 \%$ \\
$A P S$ & 13 & $41,93 \%$ \\
$C A D$ & 7 & $22,58 \%$ \\
$M V D$ & 1 & $3,22 \%$ \\
\hline
\end{tabular}


HHD: Hypertension Heart Disease

CHF: Chronic Heart Failure

APS: Angina Pectoris Stability

CAD/CHD: Coronary Artery Disease/ Coronary Heart Disease

MVD: Mitral Valve Disease

In table 5, it can be inferred that the most used drug from the CCB group is amlodipine with as many as 31 patients $(100 \%)$. Amlodipine belongs to the antihypertensive class of the dihydropyridine. According to DiPiro et al. (2017), CCB is a very effective first-line therapy as well as an antihypertensive agent. It also has a strong indication of coronary artery disease. There are two subclasses, dihydropyridine, and nondihydropyridine. CCB dihydropyridine can reduce the risk of cardiovascular incidents. As explained by Lee, Choi, Park, Ko, \& Lee (2014), from the results of their meta-analysis in comparing the effects of dihydropyridine (CCB) type calcium inhibitors namely amlodipine with other non-CCB antihypertensive therapies regarding cardiovascular outcomes. The risk of myocardial infarction decreased significantly when treated with an amlodipine-based regiment compared to the ratio of non-CCB regimens $(\mathrm{p}=0.03)$. The risk of stroke also decreased significantly ( $\mathrm{p}<0.00001)$. However, when compared as a whole with $\beta$-blockers and diuretics, amlodipine shows a comparable risk. Amlodipine regimens showed a $10 \%$ reduction in overall cardiovascular risk $(\mathrm{p}=$ 0.02). In addition to the combination of antihypertensive drugs being used, drugs for cardiovascular diseases that are widely used consist of aspirin in 14 patients $(45.16 \%)$ and Clopidogrel in 8 patients (25.80\%). Aspirin and clopidogrel are drugs that work in inhibiting platelet aggregation through different pathways. Aspirin inhibits the enzyme cyclooxygenase 1 (COX 1), thereby inhibiting the formation of thromboxane A2 (TXA2) which can induce platelet aggregation, whereas clopidogrel works by inhibiting ADP (adenosine diphosphate) which can bind with P2Y12 receptors. This type of receptors plays an important role in platelet aggregation and activation. According to Madao, Mongan, \& Manoppo (2014), aspirin in hypertension is useful to prevent the occurrence of clinical manifestations of cardiovascular diseases. Other supporting drugs for cardiovascular disorders that are widely used are from the statin group, namely simvastatin for 6 patients $(19.35 \%)$ and atorvastatin for 1 patient (3.22\%). Statins can reduce the attack of cardiovascular disease. Moreover, statins are also used for preventing cardiovascular disease in individuals who suffered from increasing risks without symptoms (Anonym., 2020). Individuals with a risk of cardiovascular disease in the next 10 years of $20 \%$ or more will benefit from statin treatment regardless of their cholesterol levels. As a note, the usage of statin must be combined with lifestyle changes and other therapies to reduce cardiovascular risk. 
Table 5. Profile of Hypertensive patients' drug usage at Undata Regional Hospital.

\begin{tabular}{|c|c|c|c|c|}
\hline Therapy class & Drug class & Drug names & Amount (n= 31) & Percentage $(\%)$ \\
\hline \multirow{13}{*}{$\begin{array}{l}\text { Cardiovascular } \\
\text { medicines }\end{array}$} & $\begin{array}{l}\text { Calcium Channel } \\
\text { Blocker }\end{array}$ & Amlodipin & 31 & 100 \\
\hline & beta-blockers & Bisoprolol & 21 & 67,74 \\
\hline & Angiotensin- & Ramipril & 5 & 16,12 \\
\hline & Converting & Lisinopril & 2 & 6,4 \\
\hline & Enzyme Inhibitor & Imidapril & 1 & 3,22 \\
\hline & Diuretic & Furosemide & 4 & 12,90 \\
\hline & ADP Antagonist & Clopidogrel & 8 & 25,80 \\
\hline & \multirow{2}{*}{ Statin } & Simvastatin & 6 & 19,35 \\
\hline & & Atorvastatin & 1 & 3,22 \\
\hline & \multirow[t]{2}{*}{ Nitrate } & $\begin{array}{l}\text { Isosorbide } \\
\text { dinitrate }\end{array}$ & 7 & 22,58 \\
\hline & & Nitroglycerin & 6 & 19,35 \\
\hline & Anticoagulants & Warfarin & 2 & 6,45 \\
\hline & Antithrombotics & Aspilet & 14 & 45,16 \\
\hline Antiansietas & Benzodiazepine & Alprazolam & 2 & 6,45 \\
\hline $\begin{array}{l}\text { Antireflux and } \\
\text { Antiulceration }\end{array}$ & $\begin{array}{l}\text { Inhibits the } \\
\text { pumping of proton }\end{array}$ & Lansoprazole & 4 & 12,90 \\
\hline Anticonvulsion & Gaba Agonist & Gabapentin & 1 & 3,22 \\
\hline $\begin{array}{l}\text { Antihyperurise } \\
\text { mia }\end{array}$ & $\begin{array}{l}\text { Inhibits oxidation } \\
\text { of xanthine }\end{array}$ & Allopurinol & 1 & 3,22 \\
\hline
\end{tabular}

Table 6 displayed the distribution of variations in the number of antihypertensive drugs that are commonly used, and from the results of this study it was found that the drugs mostly used are the combination of 2 antihypertensives with a percentage of $58.05 \%$, while the use of a single antihypertension took the proportion of $16.12 \%$, a combination of 3 antihypertensives is represented by $22.56 \%$ and 4 antihypertensive combinations to be the lowest, at 3.22\%. Dipiro et al (2015) stated that there is a high need for combination therapy involving two antihypertensive agents to be treated to hypertensive patients to achieve the targeted blood pressure. The use of combination therapy is a much better choice than increasing the dose of monotherapy to control the patient's blood pressure level if the patient receives an inadequate treatment, because the risk of unwanted drug side effects may appear due to the unusual dosage increase. Apart from that, the use of a combination of drugs can also support targeted organ protections, suppress the pathophysiology of increased blood pressure, and can reduce blood pressure levels quickly (Guerrero-García \& Rubio-Guerra, 2018). Based on ESH/ESC (2013), hypertensive patients with an increase in systolic blood pressure above $20 \mathrm{mmHg}$ and diastolic above $10 \mathrm{mmHg}$ or more are recommended to use two combinations of antihypertensive drugs, while patients who have a high risk of cardiovascular disease are recommended to use three antihypertensive combinations. On the two-antihypertensives combination therapy in Table 6, the highest amount of combined therapy was amlodipine and bisoprolol which was used by 16 patients (51.61\%). According 
to Gunawan (2016), the dihydropyridine group, amlodipine, is vasculoselective and is safe when combined with beta-blockers. As explained by Arieska et al. (2015), $\beta$-blockers are first-line drugs used in the treatments of hypertension in patients with coronary heart disease, especially those that trigger angina symptoms. This drug will work to reduce ischemia and angina because the main effect is negative inotropic and chronotropic. With decreasing heart rate frequency, the diastolic filling time for coronary perfusion will be lengthened. $\beta$-blockers also inhibit the release of renin in the patient's kidneys which will prevent heart failure. Cardioselective $\beta$-blockers $(\beta 1)$ are more recommended to be used because they do not cause intrinsic sympathomimetic activities. As further stated by Fendrikova, Kuban, \& Medical (2015), patients with hypertension and coronary heart who were treated using a fixed combination of amlodipine and bisoprolol give a significantly clearer antihypertensive and vasoprotective effects compared to the use of a temporary combination of $\beta$-blockers and dihydropyridine calcium antagonists.

Table 6. Diverse amounts of antihypertensive patients at Undata Regional Hospital.

\begin{tabular}{|c|c|c|c|c|}
\hline $\begin{array}{l}\text { Therapy } \\
\text { Regiments }\end{array}$ & Drug class & Drug names & $\begin{array}{c}\text { Amount } \\
(\mathrm{n}=31)\end{array}$ & Percentage (\%) \\
\hline \multirow[t]{2}{*}{ Single } & $\mathrm{CCB}$ & Amlodipine & 5 & $16,12 \%$ \\
\hline & Total & & 5 & $16,12 \%$ \\
\hline \multirow{3}{*}{$\begin{array}{c}\text { Combination of } \\
\text { Two }\end{array}$} & $\begin{array}{l}\mathrm{CCB}+\text { Beta } \\
\text { Blocker }\end{array}$ & Amlodipine + Bisoprolol & 16 & $51,61 \%$ \\
\hline & $\mathrm{CCB}+\mathrm{ACEi}$ & Amlodipine + Lisinopril & 1 & $3,22 \%$ \\
\hline & $\mathrm{CCB}+\mathrm{ACEi}$ & Amlodipine+Ramipril & 1 & $3,22 \%$ \\
\hline \multirow{5}{*}{$\begin{array}{c}\text { Combination of } \\
\text { Three }\end{array}$} & Total & & 18 & $58,05 \%$ \\
\hline & \multirow[t]{2}{*}{ Diuretics + ACEi } & $\begin{array}{l}\text { Amlodipine }+ \\
\text { Furosemid + imidapril }\end{array}$ & 1 & $3,22 \%$ \\
\hline & & $\begin{array}{l}\text { Amlodipine }+ \\
\text { Furosemid + Ramipril }\end{array}$ & 1 & $3,22 \%$ \\
\hline & $\begin{array}{l}\mathrm{CCB}+\mathrm{ACEi}+ \\
\text { Beta blocker }\end{array}$ & $\begin{array}{l}\text { Amlodipine }+ \\
\text { Ramipril + Bisoprolol }\end{array}$ & 3 & $9,67 \%$ \\
\hline & $\begin{array}{l}\mathrm{CCB}+\text { Diuretics + } \\
\text { Beta Blocker }\end{array}$ & $\begin{array}{l}\text { Amlodipin } \\
\text { Furosemid } \\
\text { Bisoprolol }\end{array}$ & 2 & $6,45 \%$ \\
\hline \multicolumn{3}{|c|}{ Total } & 7 & $22,56 \%$ \\
\hline $\begin{array}{l}\text { Combination of } \\
\text { Four }\end{array}$ & $\begin{array}{c}\mathrm{CCB}+\mathrm{ACEi}+ \\
\text { Beta Blocker + } \\
\text { Diuretics }\end{array}$ & $\begin{array}{c}\text { Amlodipine }+ \\
\text { Ramipril + Betaone + } \\
\text { Furosemide }\end{array}$ & 1 & $3,22 \%$ \\
\hline
\end{tabular}


In Table 7, it is inferred that an analysis of statistical examination was conducted to evaluate fasting plasma glucose levels of patients. Before the analysis test was done, a normality test was conducted. The normality test used was the Shapiro Wilk test since the number of samples in this study was less than fifty. After the normality test is done, the significant value obtained was less than 0.05 which means that the data are not normally distributed. Then, the analysis test was carried out using the Wilcoxon test. Wilcoxon statistical method is a non-parametric statistical test to determine whether there is a mean difference in 2 samples which are paired for data that are not normally distributed. Based on the results of the analysis using the Wilcoxon test in Table 7, it was obtained that the results of the level of FPG with a value of $p=0,000$ or $p<0.05$, then it can be concluded that there is a significant increase in FPG levels from the use of amlodipine antihypertension. These results are in line with the research conducted by Sandozi (2010), in which the results proved to significantly increase fasting plasma glucose levels of 20 patients was using the $\mathrm{CCB}$ antihypertensive group namely amlodipine in the doses of 2.5-10 mg once taken daily for 2-4 weeks. This is also in line with a study carried out by Prajapat, Jain, Singh, Singh, \& Agarwal (2013), which stated that amlodipine can significantly increase fasting plasma glucose levels in non-diabetic albino rabbits for 1, 2, and 6 hours after administration of $0.35 \mathrm{mg}$ per $\mathrm{kg}$ per day. A study conducted by Sushma et al. (2012) gained results of research conducted on albino rabbits which did not suffer from diabetes and the data obtained indicated significantly higher values of the test group were rabbits that had been given amlodipine orally compared to the controlled group which was only given distilled water during the 3 days of treatment, where the results obtained indicated that the mean value of the tested group was significantly higher than the controlled group (p less than 0.001). Table 7 displayed the mean value of FPG in hypertensive patients before and after treated with CCB for 3 months/ 12 weeks. In this patient, there was an increase in FPG levels from baseline 124,619 mg / dL to 141,612 mg / dL where the difference in increase was $16,993 \mathrm{mg} / \mathrm{dL}$ with a percentage of increasing of $13.63 \%$. According to DiPiro et al. (2017), one of the criteria for a diagnosis of diabetes mellitus is the patient's fasting plasma glucose to be more than or equal to $126 \mathrm{mg} / \mathrm{dL}$. Patients who suffered from type 2 diabetes mellitus, based on the examination of fasting plasma glucose patients' categories of mild to moderate hyperglycemia is $140-200 \mathrm{mg} / \mathrm{dL}$. Calcium ions play an important role in the glucose-induced phase of glucose release off pancreatic $\beta$ cells. Calcium channel blockers cause hyperglycemia by directly inhibiting insulin secretion. Thus, it is possible that amlodipine, a calcium channel blocker, can affect insulin release, and hence, the occurrence of glucose tolerance may happen to normal and diabetic individuals (Prajapat et al., 2013). According to Medscape (2019), the mechanism of insulin secretion is induced by an increase in plasma glucose levels. Glucose diffuses to beta-cells via glucose 
transporter 2 (GLUT2) and activates the glycolytic pathway, which leads to elevated levels of adenosine triphosphate (ATP). Increased levels of ATP induce ATP-sensitive $\mathrm{K}+$ channels to close and further stimulate beta-cell membrane depolarization. Then, a gate-voltage channel of calcium $(\mathrm{Ca} 2$ $+)$ is opened to increase the calcium $(\mathrm{Ca} 2+)$ cytosol and promote insulin exocytosis. According to Medscape (2018), hyperglycemic can occur because the blockade of calcium channels inhibits insulin release. From the results of the examination of FPG, in a total of 31 samples who were treated with CCB therapy excluding those suffering from a diagnosis of diabetes mellitus, 20 patients belonged to normal category FPG $(<126 \mathrm{mg} / \mathrm{dL})$ and from the 20 patients there were 5 patients with FPG evaluation results increased from mild to moderate hyperglycemia category (140 -200 mg / dL).

Table 7. Evaluation of fasting plasma glucose (FPG) levels before and after the use of CCB class drug on hypertensive patients at Undata Regional Hospital.

\begin{tabular}{|c|c|c|c|c|c|c|}
\hline \multirow[b]{2}{*}{$\begin{array}{l}\text { Category } \\
\text { FPG } \\
(n=30)\end{array}$} & \multicolumn{2}{|c|}{ Mean (mg/dL) } & \multirow[b]{2}{*}{$\begin{array}{c}\text { Percentage } \\
(\%)\end{array}$} & \multirow[b]{2}{*}{$\begin{array}{l}\text { Shapiro Wilk } \\
\text { Normality } \\
\text { Test }\end{array}$} & \multirow[b]{2}{*}{$\begin{array}{l}\text { Statistics } \\
\text { Methods }\end{array}$} & \multirow{2}{*}{$\begin{array}{c}\text { Results } \\
\text { of } \\
\text { significa } \\
\text { nce }(p)\end{array}$} \\
\hline & $\begin{array}{c}\text { FPG } \\
\text { Value }\end{array}$ & Difference & & & & \\
\hline Baseline & 124.619 & \multirow[b]{2}{*}{16,993} & \multirow[b]{2}{*}{$13,63 \%$} & \multirow[b]{2}{*}{$0,000^{*}$} & & \multirow{2}{*}{$\begin{array}{c}0,000 \\
\text { Sig. }\end{array}$} \\
\hline Evaluation & 141.612 & & & & Wilcoxon & \\
\hline $\begin{array}{l}* \\
\text { Sig. }\end{array}$ & $\begin{array}{l}\text { Signific } \\
\text { Signific }\end{array}$ & $\begin{array}{l}\text { en't distrib } \\
\text { 5) }\end{array}$ & rmally $(<0,05$ & & & \\
\hline
\end{tabular}

Table 8 displayed a clear difference value in the increase of plasma glucose levels on a dose of $5 \mathrm{mg}$ amlodipine, which was $17.36 \mathrm{mg} / \mathrm{dL}$, while at a dose of $10 \mathrm{mg}$ amlodipine, the difference is 16.11 $\mathrm{mg} / \mathrm{dL}$. Then, when observed from the difference value to compare the increase in FPG levels, amlodipine with a dose of $5 \mathrm{mg}$ can increase more of the FPG level when compared to amlodipine with a dose of $10 \mathrm{mg}$. As information, there was a greater number of patients who were treated using amlodipine $5 \mathrm{mg}$, which were 23 patients, while amlodipine $10 \mathrm{mg}$ was given to as many as 8 patients. Further research is needed to compare the effect of different doses of amlodipine $10 \mathrm{mg}$ and amlodipine $5 \mathrm{mg}$ doses on patient blood glucose levels.

Table 8. Profile of fasting plasma glucose (FPG) levels of Antihypertensives Dosage CCB Class on Hypertensive Patients at Undata Regional Hospital.

\begin{tabular}{cccccc}
\hline $\begin{array}{c}\text { Class of } \\
\text { Drugs }\end{array}$ & Drugs & Dosage & \multicolumn{2}{c}{ Mean $(\mathbf{m g} / \mathbf{d L})$} & \multirow{2}{*}{$\begin{array}{c}\text { Differences } \\
(\mathbf{m g} / \mathbf{d L})\end{array}$} \\
\hline \multirow{2}{*}{$\mathrm{CCB}$} & $\begin{array}{c}\text { Amlodipin } \\
(\mathrm{n}=23)\end{array}$ & $5 \mathrm{mg}$ & 119,81 & 137,18 & 17,36 \\
\cline { 2 - 5 } & $\begin{array}{c}\text { Amlodipin } \\
(\mathrm{n}=8)\end{array}$ & $10 \mathrm{mg}$ & 136,33 & 152,44 & 16,11 \\
\hline
\end{tabular}


In table 9, for the effect of a combination of antihypertensive drugs on fasting blood glucose levels, it is known that the highest increase in blood glucose levels is a combination of CCB, Betablocker, ACEi, and diuretics, with an increased value of $41 \mathrm{mg} / \mathrm{dL}$. According toMedscape (2020), $\beta$-blockers increased the risk of developing new-onset diabetes mellitus, especially when combined with thiazide diuretics. Regardless, this study has several limitations. The limitations in this study consist of the number of biased factors such as the use of other drugs that might affect the patients' levels, the biased lifestyle factors of the patients, as well as the patients' compliance with the treatments of antihypertensive drugs that cannot be monitored by researchers every time.

Table 9. Profile of CCB antihypertensive combination on blood glucose levels in hypertensive patients at Undata Regional Hospital.

\begin{tabular}{|c|c|c|c|}
\hline \multirow{2}{*}{ Drugs } & \multicolumn{2}{|c|}{ Mean (mg/dL) } & \multirow{2}{*}{$\begin{array}{l}\text { Differences } \\
\text { (mg/dL) }\end{array}$} \\
\hline & Baseline & Evaluation & \\
\hline $\operatorname{CCB}(n=5)$ & 109,56 & 132,68 & 23,12 \\
\hline $\mathrm{CCB}+\mathrm{BB}(\mathrm{n}=16)$ & 110,75 & 133,625 & 22,87 \\
\hline CCB+ACEi $(n=2)$ & 183 & 191 & 8 \\
\hline CCB+Diuretik+BB $(n=2)$ & 111 & 105 & 6 \\
\hline CCB+Diuretik+ACEi $(n=2)$ & 102 & 128,5 & 26,5 \\
\hline $\begin{array}{c}\mathrm{CCB}+\mathrm{ACEi}+\mathrm{BB}+\text { Diuretik } \\
(\mathrm{n}=1)\end{array}$ & 182 & 223 & 41 \\
\hline CCB+ACEI+BB $(n=3)$ & 130 & 138,33 & 8,33 \\
\hline
\end{tabular}

\section{CONCLUSION}

It can be concluded that the average value of fasting plasma glucose levels of hypertensive fasting patients using CCB for 3 months indicated that there was an average increase from baseline 124,619 $\mathrm{mg} / \mathrm{dL}$ to $141,612 \mathrm{mg} / \mathrm{dL}$ with the difference value of $16,993 \mathrm{mg} / \mathrm{dL}$. After the statistical analysis was conducted, the significance value of p 0.000 was obtained. This indicated that the use of a CCB drug, namely amlodipine, could significantly increase fasting plasma glucose patients' levels. When viewed clinically, this increase in fasting plasma glucose patients' values fall into the category of mild to moderate hyperglycemia. Because of the potential for an increase in blood glucose levels, it is necessary to pay attention to the risk of new-onset of diabetes in selecting antihypertensive therapy in hypertensive patients, to prevent the risk of cardiovascular disease.

\section{ACKNOWLEDGEMENT}

Authors would like to thank all who have helped her in completing this study, particularly to the staff of Undata Regional Hospital Palu.

\section{CONFLICT OF INTEREST}

Authors declare that there is no conflict of interest. 


\section{REFERENCES}

Alwi, I. (2012). Empirical Criteria in Determining Sample Size. Formative: Scientific Journal of Mathematics and Natural Sciences Education, 2 (2), 140-148. https://doi.org/http://dx.doi.org/10.30998/formatif.v2i2.95

Anonym. (2020). National Drug Information Center. Retrieved January 29, 2020, from http://pionas.pom.go.id/ioni/bab-2-sistem-kardiovaskuler-0/210-hipolipidemik/2104-statin

Arieska, S., Erwinanto, Sari, M., Barack, R., Anna, L. A., Nani, H., \& Soerarso, P. R. (2015). Guidelines for Managing Hypertension in Cardiovascular Diseases. Guidelines For Hypertension Management in Cardiovascular Diseases. Association of Indonesian Cardiologist Specialists.

Aryzki, S., \& Akrom. (2018). The Effect of Brief Counseling on Fat Consumption in Hypertensive Patients in Dr. H . Moch Ansari Saleh General District Hospital, Banjarmasin. 5(1), 33-40.

Barnett, L. A., Prior, J. A., Kadam, U. T., \& Jordan, K. P. (2017). Chest pain and shortness of breath in cardiovascular disease: A prospective cohort study in UK primary care. BMJ Open, 7(5), 110. https://doi.org/10.1136/bmjopen-2017-015857

Degeeter, M., \& Taylor, S. R. (2018). Amlodipine-induced hyperglycemia. 35(5), 181-183.

Central Sulawesi Provincial Health Office. (2017). Health Profile of Central Sulawesi Province in the year of 2017. Palu.

DiPiro, J. T., Talbert, R. L., Yee, G. C., Matzke, G. R., Wells, B. G., \& Posey, M. (2017). Pharmacotherapy: A Pathophysiologic Approach, Tenth Edition. 3146-3154.

Fendrikova, A., Kuban, V. S., \& Medical, S. (2015). Effectiveness of Fixed-Dose Combination of Bisoprolol And Amlodipine in Patients With Arterial Hypertension and Coronary Heart Disease. Journal of Hypertension, 33, 2015.

Guerrero-García, C., \& Rubio-Guerra, A. F. (2018). Combination therapy in the treatment of hypertension. Drugs in Context, 7, 1-9. https://doi.org/10.7573/dic.212531

Gunawan, Sulistian Gan. (2016). Pharmacology and Therapy (6th ed.; Gunawan sulistia Gan, S. Rianto, Nafrialdi, \& Instiaty, Eds.). Jakarta: Pharmacology and Therapeutics Department, Medical Faculty Universitas Indonesia. 
Harigustian, Y., \& Dewi, A. (2016). Characteristic Descriptions of Patients Suffering from Heart Failure in the Ages of 45-65 Years Old at PKU Muhammadiyah Gamping Hospital Sleman. $1(1), 55-60$.

Medscape. (2018). treatment of CCB toxicity. Retrieved from https://emedicine.medscape.com/article/2184611-overview

Medscape. (2019). What is insulin secretion? Retrieved from https://www.medscape.com/answers/2089224-170948/what-is-insulin-secretion

Ministry of Health, Republic of Indonesia. (2014). Hypertension Infodatin, (Hypertension), 1-7. https://doi.org/10.1177/109019817400200403

Ministry of Health, Republic of Indonesia. (2018). Main Research Results of Basic Health in the Year of 2018. Ministry of Health, Republic of Indonesia., 1-100. https://doi.org/1 December 2013

Lee, S. A., Choi, H. M., Park, H. J., Ko, S. K., \& Lee, H. Y. (2014). Amlodipine and cardiovascular outcomes in hypertensive patients: Meta-analysis comparing amlodipine-based versus other antihypertensive therapy. Korean Journal of Internal Medicine, 29(3), 315-324. https://doi.org/10.3904/kjim.2014.29.3.315

Lukito, A., Eka, H., \& Made, H. (2019). Consensus of Management of Hypertension in 2019.

Madao, D. A., Mongan, A. E., \& Manoppo, F. (2014). Relationship Between the Lengths of Treatments using Aspirin with the Aggregation of Platelet Values in Hypertensive Patients at RSUP Prof. Dr. R. D. Kandou Manado. Journal E-Biomedics, 2(2), 545-550. https://doi.org/10.35790/ebm.2.2.2014.5110

Prajapat, R., Jain, I., Singh, S., Singh, S., \& Agarwal, P. (2013). The effect of amlodipine on plasma glucose level and its interaction with oral hypoglycemic drugs in albino rabbits. International Journal of Basic \& Clinical Pharmacology, 2(6), 768. https://doi.org/10.5455/23192003.ijbcp20131218

Sandozi, T. (2010). Study of the effect of Amlodipine on plasma glucose level. Asian Journal of Medical Sciences, 1, 4-5. https://doi.org/10.1124/pr.57.4.5

Saputra, B. R., \& Indrawanto, I. S. (2013). Profiles of Hypertensive Patients at Jombang District General Hospital in the Period of January-December 2011. 9, 116-120. 
Starry, R. (2012). Searching for the Causes of Chest Pain?: Cardiac and Non-cardiacs. Yarsi Medical Journal, 20(1), 45-53.

Sushma, N., Suresha, Huralikuppi, Ashwini, Satish, \& Brahadeesh. (2012). Effect of Amlodipine on Oral Glucose Induced Glycemic Changes in Normal Albino Rats. International Journal of Pharmaceutical Sciences and Research, 3(09), 18.

Waty, M., \& Hasan, H. (2013). Prevalence of Hypertensive Heart Disease in Congestive Heart Failure Patients at RSUP H. Adam Malik. E-Journal Medical Faculty USU, 1(1), 1-5.

World Health Organization. (2013). A global brief on Hypertension. A Global Brief on Hypertension, 9 